\title{
LOCAL MANIFESTATIONS OF THE URQUHARTITE MOVEMENT
}

David Urquhart (1805-1877), the inspirer of the agitation that took his name, has been succinctly described as "an ex-diplomatic official who carried his Russuphobia to an almost pathological extreme"." As an official at the British Embassy in Constantinople, Urquhart, whose admiration for the Turks knew no bounds, had tried to engineer a war between Britain and Russia. In his eccentric way he ascribed his subsequent removal from a position of diplomatic responsibility to the work of Russian agents in the British Foreign Office. The phobia grew. David Urquhart, a man of compelling charm and deep idealism, came to regard the Czar as the Antichrist and to see his minions everywhere. In particular, Urquhart turned his attack on Lord Palmerston, the Foreign Secretary who had recalled him to England in July, 1837, and whom he now represented as an agent in an international conspiracy.

Beginning in 1837, Urquhart tried to win over the middle class element in British cities, and apparently secured a measure of success in Glasgow, Leeds, Hull and Birmingham. ${ }^{2}$ In Newcastle a newspaper called The Northern Liberator espoused his cause. Success among the middle classes was short-lived, however, and in 1839 the Tory Urquhart (he actually sat as a Tory Member of Parliament between 1847 and 1852) began to woo the working classes. ${ }^{3}$ Wherever he could find support he set up "Committees for the Study of Diplomatic Documents". But, quite apart from the extreme eccentricity of much of what Urquhart had to say, the intellectual demands made on these élite cells of working-class acolytes were notoriously high, and it was not until the

1 A. R. Schoyen, The Chartist Challenge (London, 1958), p. 89. For a general biography of Urquhart see G. Robinson's study (Oxford, 1920). There is an interesting note on Urquhart in The Dictionary of National Biography (London, 1899), Vol. LVIII, pp. 43-45.

2 Urquhart's activities in the 1830 s are summarized in J.H. Gleason, The Genesis of Russophobia in Great Britain (Cambridge, Mass., 1950).

"Asa Briggs, "David Urquhart and the West Riding Foreign Affairs Committee", in: The Bradford Antiquary, New Series, Part 39, 1958, p. 6. 
outbreak of the Crimean War (a struggle in which early disasters brought Palmerston to the office of Prime Minister) that the Urquhartite agitation achieved mass proportions. ${ }^{1}$

Superficially, therefore, the Urquhartite movement was a quasipolitical agitation into which "the fearless David" drew individuals "as cranky as himself". There was, indeed, more than a touch of monomania in Urquhart's make-up, and at this level, at any rate, it is doubtful whether the term "movement" should be applied to the activity that he apparently inspired. Not surprisingly, when the subject is touched on, writers tend to mention only the more obvious features: Urquhart's personal hatred of Palmerston; his never-ending search for "traitors"; his failure to win and retain upper and middle class support; the ultimate adherence of working-class elements to his cause; the great outburst of activity with mass meetings held between 1854 and 1856; and the rapid decline of the agitation after the latter date. ${ }^{2}$

Perhaps, however, the time has come when work should begin on a more radical assessment of Urquhartism as being of significance in both the social and political history of Britain in the nineteenth century. Clearly, there are several problems which the social historian might well consider to be of importance. How was it possible for an agitation with such an improbable basis to attain mass proportions, even for a relatively short period of time? What was the precise nature of the relationships between Urquhartism and the representatives of movements of a more obviously "social" nature? To what extent was the agitation, like those inspired in earlier years by such men as "Orator" Hunt and Feargus O'Connor, an outwardly political movement which drew its real strength from a consciousness of social injustice and economic ill? It is, of course, a sociological truism that no group exists in isolation: that all groups tend in some degree to mirror the attitudes of the wider society of which they are part. To what extent is this true of the Urquhartite groups? Conversely, to what degree did distinctively regional factors lead to the appearance of local deviations and peculiarities in the broader movement? And, finally, how did Urquhart and his supporters explain the existence of the rottenness that they claimed to see in contemporary British society, and what long-term solutions had they to offer?

These are, indeed, difficult questions, and to answer them fully and satisfactorily would be the work of many years. On the other hand, it might well be that a detailed study of Urquhartism in a distinctively

1 See W. H. G. Armytage, "Sheffield and the Crimean War", in: History Today, Vol. 5, No 7, July, 1955, p. 479.

2 See, for instance, A. J. P. Taylor, The Trouble Makers (London, 1957), pp. 46-60. 
local context might well be of service to the general worker in the field of the nineteenth century in seeking to trace complex patterns of motivation and relationships between movements with outwardly dissimilar characteristics.

It has, of course, long been recognized that, along with Newcastle, Sheffield was a major centre of Urquhartite activity. Up to a point, it is not difficult to see why this should be so. Perhaps significantly, it was not until the eighteen-fifties that the town became a centre of large-scale industry. ${ }^{1}$ The staple trades of Sheffield - cutlery and edge-tool making, the manufacture of surgical instruments, silversmithing and other plate metal working - demanded a high degree of skill and not a little initiative. Standards of literacy among the workmen were relatively high. In the eighteen-forties the town supported five separate institutions for adult education ${ }^{2}$ and had become a stronghold of Moral Force Chartism. ${ }^{3}$ The vagaries of an extensive and delicately balanced foreign trade had long taught Sheffielders that what happened abroad could fundamentally affect "the bread and cheese question" in their town. Thus J. S. Buckingham, one of the first two MPs elected in the borough after its enfranchisement in 1832, was pledged to sweep away the last remnants of the East India Company's monopoly in the Far East, and Sheffield's dependence on conditions of economic and political stability in the United States of America was underlined in the local parody of "Yankee Doodle":

"Yankee Doodle borrows money.
Yankee Doodle spends it.
Then he snaps his fingers at
The silly flat that lends it!"

On a more serious note, it is not irrelevant to point out that there had been a distinct broadening of ultra-Radical sympathies in the town in the late eighteen-forties, as a highly original address to the French Revolutionaries in 1848 had indicated. ${ }^{4}$ An intriguing mixture of Moral Force Chartism, Owenite thought and Continental Socialist

1 W. H. G. Armytage, op. cit., p. 476.

2 A Mechanics' Library, Mechanics' Institute, Owenite Hall of Science, Church of England Educational Institute and a People's College. The latter inspired an important movement in adult education led by F. D. Maurice.

3 John Salt, Chartism in South Yorkshire (University of Sheffield Local History Pamphlets, No 1, 1967).

4 John Salt, "English Radicalism, a Neglected Document", in: Notes and Queries, Vol. 13, September, 1968, pp. 332-333. 
doctrine, the document called for a complete replanning of French, indeed European, society. After asserting that governments were merely "delegated authorities" and that no revolution that did not lead directly to Man's intellectual and moral improvement could achieve permanent good, the document urged the French to guarantee "remunerative employment according to choice, capacity and public necessity", together with a free education and provision in sickness and old age. "Individuals", it was asserted, "owe all to society, inasmuch as they receive all from it. Each should assist all in securing individual wealth, happiness and honour." Money was not needed: "real wealth" alone was necessary. In the concluding paragraphs the address suggested that "all the States of Europe should be federated in one great and mighty Republic of nations whose example shall be followed throughout the world."

It is also significant that in subsequent years - and even before the influence of Urquhart could be seen to be at work - Sheffield ultraRadicals came to point to "the accursed Russian autocrat" as the keystone of tyranny and reaction in Europe generally, ${ }^{1}$ and in 1851 they sent representatives to Southampton to meet Kossuth, the Hungarian leader who, as A. J. P. Taylor suggests, was to play a vital rôle in shaping left-wing attitudes in Britain in the eighteen-fifties. ${ }^{2}$

From all this it is clear that in several ways the general situation in Sheffield at mid-century favoured the growth of Urquhartism in the town. On the other hand, it is also true that, in a very real sense, the association of Sheffield with Urquhartism was a testament to the domination of one man in local ultra-Radical politics in the late eighteen-forties and early eighteen-fifties. This was Isaac Ironside, a Chartist and Owenite, who, since the collapse of Chartism as a national movement had led a "Democratic" party in Sheffield, and who was still drawing attention to the social results of a model workhouse community in the Rivelin Valley, which his socialist agitation had inspired..$^{3}$ As a figure of national significance in the Urquhartite movement, Ironside, as owner of The Sheffield Free Press, was of particular importance not only in that he provided Urquhart with a medium for his propaganda before Urquhart's London-based Free Press was founded to spread his peculiar gospel, but also in that he enlisted the services of Karl Marx for his unashamedly propagandist journal. Marx hated Russia and Palmerston almost as much as did the

1 The Sheffield Free Press, 1 November, 1851, p. 5.

2 A. J. P. Taylor, op. cit., p. 58.

${ }^{3}$ For an account of this project see John Salt, "Isaac Ironside and the Hollow Meadows Farm Experiment", in: Yorkshire Bulletin of Economic and Social Research, Vol. 12, No 1, March, 1960. 
Urquhartites, but personal relationships were not always easy. Ironside published in his newspaper columns Marx's analysis of the Kars Blue Books, but there was friction when the payment for the contribution was delayed and when Ironside criticized the length of articles which "entombed" his newspaper. We find Marx complaining to Engels about "those Sheffield Calibans". ${ }^{1}$ On the other hand, Marx wrote to Ironside on 21 June, 1856, to say that the was willing to contribute a regular column. ${ }^{2}$

It is, however, with Ironside as a local leader that this article is particularly concerned. Certainly to have maintained a vigorous ultraRadical movement in the early eighteen-fifties when, as the organ of the remnants of Chartism confessed, "a deep slumber had fallen on the people", ${ }^{3}$ was no mean achievement, and the reasons why Ironside had been able to succeed are both interesting and relevant to this present study.

As a local demagogue, Ironside had long been skilled in the art of arousing interest and support by exposing "abuses", particularly in the sphere of local administration. Even his opponents credited him with having aroused interest in a town council which between 1843 , when Sheffield was incorporated, and 1847, when Ironside was returned for the Ecclesall Ward, had been regarded with "an indifference worthy of all condemnation".4 A similar skill had also been shown in the creation and manipulation of small groups of the politically dedicated. In October, 1848, a Sheffield newspaper reported that "in some wards, and probably in all, there have existed Chartist committees, prepared both to name their men and work for them with great unanimity and vigour." Already, apparently, a central committee had been formed "for the purpose of giving and receiving information which would

1 See F. Mehring, Karl Marx (London, 1936), p. 244; M. Beer, The Life and Teaching of Karl Marx (London, 1925), p. 81; J. Saville, Ernest Jones, Chartist (London, 1952), p. 240.

2 See Marx-Engels, Werke (East Berlin), Vol. 29, pp. 537-538. Marx's relations with the Urquhartites are, in fact, somewhat complex. In June, 1854, Marx wrote to Lassalle saying that he did not wish to be associated with Urquhart in that, apart from his shared opinion of Palmerston, he was "diametrically opposed" to "this gentleman". Ibid., Vol. 28, p. 608.

In 1855, however, The Free Press began to publish a series of lengthy articles by Marx on "Revelations of the Diplomatic History of the Eighteenth Century". Perhaps there will always be mystery here, but for Marx's diplomatic views see The Eastern Question (1899), an anthology edited by Edward and Eleanor Marx Aveling.

3 The Northern Star, 4 January, 1851, p. 4.

4 The Sheffield Mercury of 14 November, 1846, had lamented that "the right of voting exists, but the practice of the right is not cared for". 
necessarily be required before the election". ${ }^{1}$ In November 1848 , no less than seven of the fourteen successful candidates in the local government election were sponsored by the Chartists, and in November, 1849, the "Ironside Party" in the Sheffield Town Council numbered twenty-two. Meanwhile the Sheffield Chartists (who were now beginning to call themselves Democrats) were instrumental in securing the return of J. A. Roebuck as Member of Parliament for the town, The Times confessing that "if one party more than another solicited Mr. Roebuck to stand, and contributed materially to his election, it was the party of the Charter." In July, 1851, the organization of the Sheffield Democrats was improved by the establishment of a Central Democratic Association, with delegates sent from each ward, to "watch over, promote and protect every democratic movement and principle and to bring a considered and systematic organization to bear on all such movements". ${ }^{2}$

In 1850 it seemed possible that Sheffield, in defiance of national trends, might well have an ultra-Radical mayor presiding over a town council with a Democratic majority. It is, however, incontrovertible evidence of Ironside's personal hold over his followers at this critical point in his career that he was able virtually to turn his back on the immediate prospect of success in the orthodox field of local politics and to enlist the support of the "Ironside Party" for a series of experiments, based on anarchist theory, in the field of political education.

Ironside's interest in anarchism (of which, as we shall see, his adherence to Urquhartism was, in an important sense, the ultimate expression) was rooted in his experience as a Moral Force Chartist and Owenite. As a leader of the Sheffield Chartists he had warned his supporters of the dangers of putting faith in mere forms of political organization: “... if Governments were overturned by ignorance, the same ignorance would re-establish them." 3 As "the person more publicly connected with the Sheffield (Owenite) institution than any other member", he had invited Madame D'Arusmont (Frances Wright) to expound to audiences at the Hall of Science her plan "to substitute for Government universal liberty and perfect order", 4 and, indeed, for some years Ironside refused to vote in the town council chamber on

1 The Sheffield Independent, 28 October, 1848, p. 8. As early as October, 1847, each ward selection committee had sent two delegates to a special meeting at the Democratic Reading Room in Queen Street, Sheftield. See The Northern Star, 2 October, 1847, p. 8.

2 The Sheffield Free Press, 12 November, 1852, p. 5.

3 The Sheffield Iris, 23 March, 1848, p. 7. See also John Salt, Chartism in South Yorkshire (Sheffield, The University, 1967), pp. 23-27.

4 The Sheffield Iris, 24 February, 1848, p. 5. 
the grounds that voting represented an exertion of force to coerce an unconvinced minority.

In 1851 Ironside came under the spell of Toulmin Smith, an antiquarian and constitutional lawyer whose researches had led him to consider that the existing system of delegated political responsibility was "only a faint shadow of the direct power which the people possessed in early stages of civilization". ${ }^{1}$ An encroaching centralization of authority, argued Smith, had come to endanger that "wholesome public opinion which was of the utmost importance to the well-being of the state". In these circumstances it was suggested that power should be transferred to revived local institutions in which the individual citizen could play a direct and meaningful part. "Parliament", said Toulmin Smith, "is a result and not a source. In this single phrase is embodied the whole of my political philosophy."

In accordance with the ideas of a man whom he described as "England's greatest constitutional lawyer", Ironside (who, as we have seen, had extensive experience in the creation and manipulation of ward committees) began to organize "wardmotes" in Sheffield. "Local self-government", he argued, "cherishes and develops every moral and intellectual faculty and gives each of them in every man full scope for action; it humanizes and elevates and kindles every kindly charity."2 It is significant that during the period of the Urquhartite agitation Urquhart and Ironside were to make similar claims for the promotion of an interest in international affairs.

Ironside's opportunity to create wardmotes came in December, 1850, when the Sheffield Town Council agreed to Richard Solly's scheme for the calling of meetings of burgesses in each ward to discuss the application of the Free Public Libraries Act to Sheffield. Attendance at the meetings was disappointing, but, with characteristic opportunism, Ironside persuaded the burgesses of Nether Hallam to appoint a

1 The Sheffield Free Press, 14 February, 1852, p. 2. Toulmin Smith's Local Self Grovernment and Centralization had been reviewed in the local press in April, 1851, and subsequently Ironside read fragments of Smith's Municipal Address to the Burgesses of Farringdon Without and his Governments and Commissions Illegal and Pernicious to a restless Town Council. Toulmin Smith's influence was not entirely short-lived: his researches into gild organization are constantly referred to in P. Kropotkin's Mutual Aid (London, 1902). He also did something to promote interest in local records: see his letters to Sir F. Madden, British Museum Egerton Collection, 2848, 106 and $110 \mathrm{ff}$.

2 The Sheffield Free Press, 12 April, 1851, p. 6. Ironside constantly stressed the importance of that "practical education which the revivification of our municipal institutions would certainly create", stressing that "the only hope of properly educating the masses was to interest them in something that touched their pockets". See The Sheffield Times, 13 March, 1852, p. 7; 20 November, 1852, p. 7. 
committee charged with the duty of arranging regular meetings to discuss such questions as the appropriation of the Church Burgesses' Trust, the problem of youthful hooliganism, the building of a vestry hall, and the need to develop educational facilities locally.

Nether Hallam thus led the way, and with the blessing of the Central Democratic Association, which ultimately became "a sort of Upper House" in relation to these tiny local parliaments, an Ecclesall Wardmote began to meet in November, 1851, attracting forty persons to its second meeting. The St. Philip's Wardmote also began to meet in November, 1851, and in December of the same year a similar organization was created in the St. George's Ward.

Having established the wardmotes, Ironside's problem was to extend the range of their activities and to give them a measure of real power, particularly in local affairs. What is, of course, especially interesting in the light of this present investigation is that, almost from the beginning, the wardmotes began to make pronouncements on foreign policy. In December, 1851, for instance, a meeting at the Queen's Arms, Portmahon, not only "tried" a youth for "Sabbath desecration", discussed the state of the local water courses and took up the question of the victimization of trade unionists, but also considered the implications of the Kaffir War and agreed to memorialize the Foreign Secretary, urging him not to recognize the new régime in France, "whose form of government was based on such a perjured, violent and illegal assumption of power". ${ }^{1}$

Ironside's attempts to give real power to the wardmotes were less happy, however, and did much to create the situation, coinciding with the beginning of the major Urquhartite agitation, whereby Ironside's political fortunes in Sheffield were sufficiently low to impel him to ally himself with a national movement, but at the same time his latent influence in the town was sufficiently strong to allow him to make a major contribution to that movement. It is true that Ironside was able, in his capacity as Chairman of the Sheffield Highway Board, to use the "permission" of the wardmotes to spend money on the building

1 Ibid., 13 December, 1851 , p. 6 . On other occasions wardmotes discussed the treatment of Kossuth in Turkey and the problem of the maintenance of French troops in Rome. In the breadth of their discussion the wardmotes appear to have had something in common with the Owenite institution which Ironside had run in the eighteen-forties. See John Salt, "The Sheffield Hall of Science", in: The Vocational Aspect, Vol. XII, No 25, pp. 133-138. In their attempts to promote happy social relationships (The Sheffield Free Press, 7 February, 1852, referred to them as "bands of jolly fellows"), they have a similarity to earlier Owenite groups. See, for instance, G. J. Holyoake, The History of Co-operation (London, 1906), p. 135. To their opponents, the supporters of the wardmotes were known as "pot house politicians". 
of deep sewers. ${ }^{1}$ But the attempt to secure Toulmin Smith's election as MP for Sheffield led to humiliating failure; ${ }^{2}$ an assertion that the wardmotes had the right to elect aldermen in open meeting produced ridicule, so that even The Free Press ceased to refer to "Alderman Ironside"; $;$ and an attempt to promote a second gas company for Sheffield without recourse to Parliament led to charges of a betrayal of the town's interest when a Committee of the House of Commons insisted on the amalgamation of the old and the new companies. ${ }^{4}$ Perhaps most important of all, however, the attempts of the wardmotes to turn the Democratic town councillors into mere delegates produced tension and disruption in the Ironside Party. Thus Isaac Schofield and William Harvey, two of the ablest Democrats in the Sheffield Town Council, rejected the wardmotes as early as May, $1852 .^{5}$ Perhaps, in the light of modern sociological theory, it is possible to see in this evidence of a deeper conflict between the minor business and professional men, such as Charles Alcock, who had been attracted to the Ironside Party by the prospect of popular support and the attainment of local office, and the "old guard" of working-class Chartists, such as Thomas Hague, who, along with younger adherents, lacked both the wealth and leisure to become members of the Town Council. Certainly Ironside appears largely to have shed the remnants of lower middle-class support by the time he appeared as an Urquhartite leader. In May, 1856, he was to say of one of his meetings that "he did not think that there was a man there, besides himself, who was a voter", 6 and he was later to refer to the Sheffield Foreign Affairs Committee as "a committee of working men".?

In 1854, therefore, a number of factors made Sheffield peculiarly receptive to Urquhartite propaganda. Anti-Russian feeling was already deeply ingrained, as we have seen, and, as early as January, 1854,

1 There were complaints in Sheffield that "the board spent almost every shilling illegally in providing sewers." The Sheffield Independent, 17 June, 1854, p. 8. This was in defiance of the 67 th Section of the General Highway Act.

2 See R. E. Leader, The Life and Letters of John Arthur Roebuck (London, 1897 ), p. 251, and the manuscript autobiography of George Hadfield, MP, in the Sheffield Central Library.

3 See comment in The Sheffield Times, 17 May, 1851, p. 7.

- John Salt, "The Sheffield Consumers' Gas Company, an Early Co-operative Enterprise", in: The Co-operative Review, September, 1965.

5 The Sheffield Times, 8 May, 1852, p. 7. By November, 1853, when Ironside was defeated in the election for representatives for the Ecclesall Ward in the Sheffield Town Council, the Ironside Party had virtually ceased to exist in the council chamber. For some months Ironside sat for an uncontested ward.

B The Free Press, 3 May, 1856, p. 4.

7 The Sheffield Independent, 9 June, 1863, p. 6. 
Ironside was calling for "an honest war" against Russia. ${ }^{1}$ In Sheffield, too, economic conditions were deteriorating at a time when Government's handling of the Middle East situation was passing from "ineptitude to futility". ${ }^{2}$

To take advantage of this situation the Sheffield ultra-Radicals (though weakened by the failure of some of their leader's eccentric schemes) had an orator of considerable skill and unquestionable temerity; a tradition of intellectual investigation; an accumulated expertise in the organization and manipulation of small groups with high pretensions; and a newspaper in the shape of The Free Press, which was now controlled both financially and editorially by Isaac Ironside. ${ }^{3}$ Here, in fact, was a peculiarly important point about Sheffield Urquhartism. As an old Chartist and Owenite, Ironside, a devoted but essentially independent-minded associate of Urquhart, continued to stress to his working-class audiences that his activities were related to their living standards, to what he continually referred to as "the bread and cheese question". In November, 1855, for instance, he stressed that both prices and taxes were rising, and accused the Government of a criminal plot to keep cheap wheat from the Danubian Principalities from reaching Britain. ${ }^{4}$ Here, indeed, was the welding of Urquhartism to an older political tradition, and The Sheffield Free Press was never to become an absolutely "purist" medium for Urquhart's propaganda.

Perhaps not surprisingly, in September, 1854, Sheffield was the scene of "the first of the really big Urquhartite demonstrations", 5 and in the following months numerous excited public meetings were held with Ironside as "the principal actor in the proceedings". ${ }^{6}$ At the very first meeting motions "altogether condemnatory" of Lord Aberdeen's conduct of the war were passed - motions which probably stimulated J.A. Roebuck's celebrated demand in the House of Commons for an enquiry into the "heart-rending" condition of the army

1 The Sheffield Times, 14 January, 1854, p. 6.

2 A. R. Schoyen, op. cit., p. 239. There was, in fact, considerable distress in Sheffield at this period. In December, 1855, a representative of the Table Knife Hafters' Union was to write: "In the year that is past many of us have been paupers, and nearly all have been brought to the threshhold of ruin. Our wives and children have been badly fed and thinly clad." See The Sheffield Independent, 29 December, 1855 , p. 5.

3 See W. Shepherd, Starting a Daily in the Provinces (London, 1876), p. 82; C. D. Collett, History of the Taxes on Knowledge (London, 1899), Vol. 2, p. 57.

- See The Sheffield Independent, 10 November, 1855, p. 6.

5 W. H. G. Armytage, "Sheffield and the Crimean War", in: History Today, Vol. V, p. 467.

B The Sheffield Times, 30 June, 1855, p. 10. 
before Sebastopol. ${ }^{1}$ The Aberdeen Government fell, and the full blast of Urquhartite propaganda was then turned on Lord Palmerston, the new Prime Minister.

Stimulated by its founder's great personal hatred of Palmerston and his genuine belief that the Czar was the Antichrist, the Urquhartite Movement became increasingly hysterical. Urquhart and his disciples saw Russian influence everywhere. Lord Aberdeen had early been accused of being in "secret, dishonest and clandestine communication" with Russia, and G. S. Phillips, who was for a period editor of The Sheffield Free Press, had claimed that he had "ten distinct charges of high treason against Palmerston", but these attacks almost paled into insignificance when it was suggested that the Prime Minister was a leading Russian agent and that his ambition was to become the "Viceroy" of a Russian-controlled Britain. ${ }^{2}$ According to the Urquhartites, the war against the Czar was a "great sham", designed to protect Russia from the Turks, who, it was said, were about to smash Russia when the British intervened. ${ }^{3}$ The final result of Palmerston's work, it was said, would be to turn England into "a den of wild beasts". ${ }^{4}$ The charges in The Free Press multiplied: Lord Clarendon, the Foreign Secretary, was "a liar, traitor and villain"; Mazzini, Kossuth and Ledru-Rollin were revolutionists playing the Russian game; Robert Lowe, destined to be the chief apologist for "payment by results" in education, was "a conscious Russian agent"; and Lord Durham and Gibbon Wakefield were in league with the Czar; The Manchester Guardian was "the ally and apologist of Russia"; and the editor of The Times was in Russian pay; "the English ambassador destroyed the Turkish fleet at Sinope... the English troops were purposely encamped on the plague ground at Devna"; the British Government was deliberately keeping the price of bread high by refusing to allow into the country shipments of Turkish grain. ${ }^{5}$ These and similar fantastic allegations were constantly made by Ironside and his newspaper.

Other features of the agitation were reflected in the work of the

1 The Sheffield Independent, 30 September, 1854, p. 10; R. Leader, op. cit., p. 259 ; W. H. G. Armytage, op. cit., pp. 467-469.

2 The Sheffield Times, 30 September, 1854, p. 7; The Free Press, 10 November, 1855 , p. 4, and 5 April, 1856 , p. 2. G. S. Phillips had been a supporter of the Sheffield Hall of Science. See The Sheffield Iris, 18 November, 1847, p. 5.

3 The Free Press, 5 April, 1856, p. 2. See also David Urquhart, The Queen and the Premier (London, 1857), p. 6, and The Military Strength of Turkey (London, 1868), p. 2.

4 The Free Press, 3 November, 1855, p. 2.

5 The Sheffield Independent, 10 November, 1855, p. 6. 
Sheffield Foreign Affairs Committee (originally one of sixty-nine similar bodies) which was formed in June, 1855. ${ }^{1}$

The first object of the Sheffield Foreign Affairs Committee was to make a thorough study of those aspects of national or international policy which affected the honour and well-being of the country as a whole. This work was, in fact, taken very seriously by the working men who formed the membership of the organization, and Ironside, who found Blue Books "equal to the most thrilling romances", insisted that the subjects discussed, quite apart from their political importance, should be intellectually stimulating. ${ }^{2}$ Masses of documents were collected and there was a constant flow of letters to individuals thought capable of supplying information on vague or controversial points of public policy. The work undertaken by "these new schools", said The Free Press of 8 March, 1856, "would not escape the eye of the future historian."

Yet the Sheffield Foreign Affairs Committee, "an association for the study of the present" seeking "to render events comprehensible to themselves and to others", was no mere collection of working-class dilettanti. Urquhart himself stressed that such institutions should "denounce", and thus the members of the Sheffield organization consciously constituted a pressure group, influencing public opinion by rooting out scandals in the country's administration, "publishing... proceedings and inviting discussion", organizing meetings, canvassing important individuals and sending petitions to Parliament. In 1856, for instance, the Committee pestered Sir Charles Napier to disclose evidence of treachery in the conduct of British naval operations. ${ }^{3}$ In 1858 it organized a local protest against the annexation of Oude, and in 1859 it called on the Sheffield Town Council "to elicit the truth in reference to the hostilities in China, and to bring the offenders to justice". ${ }^{4}$ In 1868 there were complaints about Ironside's "cool effrontery" in writing letters to the Queen and the Lord Chancellor. ${ }^{5}$

The Sheffield Foreign Affairs Committee was thus, in certain aspects, an institution concerned with study, investigation and agitation. It was also supposed to have constitutional importance, for Urquhart, not less than Toulmin Smith, wished to create a political system in which "nothing could be undertaken by the Government until the sanction, not of Parliament, but of the whole nation and every

1 See A. G. Stapleton, A Day With One of the Committees (London, 1875), p. 1; The Sheffield Times, 23 June, 1855, p. 8.

2 The Free Press, 10 November, 1855, p. 3.

${ }^{3}$ Ibid., 12 April, 1856, p. 1; 26 April, 1856, p. 4.

4 The Sheffield Independent, 12 February, 1859, p. $10 ; 18$ February, 1859, p. 6.

5 Ibid., 12 March, 1868, p. 4. 
fragment of it was obtained". 1 One aim behind Urquhart's fantastic charges against the Government was to illustrate to the people of Britain the extent to which their country had been debased by a political system which allowed the leaders of the nation to be corrupted by the exercise of unchecked power. Thus, like the wardmote of the early eighteen-fifties, the Foreign Affairs Committee was regarded by its promoters as a means by which a progressively more enlightened and knowledgeable populace might come to exert a very real control over the affairs of State. Along with the revived Shire Moot, the restoration of municipal control over taxation, the appointment of each minister directly by the Crown, the restoration of impeachment as a means of rendering ministers fully responsible to a House of Commons elected on Manhood Suffrage, the publication of the Minutes of the Cabinet, the ending of secret diplomacy and the abolition of permanent embassies abroad, and the restoration of the Privy Council to its "pristine vigour", the Foreign Affairs Committee was a device whereby the "restoration of the laws of England" might be brought about, an electorate brought into being that was both "intelligent" and responsible, and society as a whole regenerated. ${ }^{2}$ As a quasi-educational institution, the Sheffield Foreign Affairs Committee represented Isaac Ironside's last major attempt to solve the problems of motivation in adult education by linking instruction with the political fears and aspirations of the masses.

A study of the affairs of the Sheffield Foreign Affairs Committee shows that although it remained in existence virtually until Ironside's death in 1870 , it rapidly lost vitality and influence after the outburst of almost frenzied activity that characterized the years 1855 and 1856 . The Committee had some isolated triumphs, it is true. In October, 1857, its probe into the affair of the Reverend Magee of Bath, who had been reported as calling for vengeance on the "diabolical ruffians" concerned in the Indian Mutiny, resulted in the publication of the relevant letters in the August columns of The Times. ${ }^{3}$ In 1858 the Foreign Affairs Committee helped to stimulate local opposition to the Conspiracy

1 See David Urquhart, The Channel Islands, Norman Law and Modern Practice (London, 1844), p. 1.

2 Ibid., p. 15. See The Free Press, 8 December, 1855, p. 4; 15 March, 1856, p. 6; and 2 August, 1856, p. 3. See also The Sheffield Independent, 13 February, 1868, p. 3, and David Urquhart, The Four Wars of the French Revolution (London, 1874), p. 45.

3 Ironside incurred much unpopularity in Sheffield by trying "to get up a sort of sympathy with the black villains" involved in the Indian Mutiny. See The Sheffield Independent, 31 October, 1857, p. 6. The Urquhartites insisted that the root cause of the Indian Mutiny was "that those who rule are certain of impunity for whatever they do." See David Urquhart, The Rebellion in India (London, 
to Murder Bill, and in the same year organized the agitation which led to the abandonment of a proposed comprehensive Improvement Bill for Sheffield. ${ }^{1}$ In 1857 George Hadfield, MP, had been induced to speak strongly against secret diplomacy, and as late as 1866 no less a person than the Lord Advocate, in the course of a lengthy correspondence, tried patiently to set Ironside to rights on the then hackneyed subject of the Right of Search at Sea. ${ }^{2}$ But, meanwhile, the affairs of the Sheffield Foreign Affairs Committee had long been far from encouraging. As information about its nature and composition became more widespread, "contumelious treatment" at the hands of the individuals and bodies it pestered with advice, admonitions and requests for information became increasingly commonplace. ${ }^{3}$ In 1857 it was found that the Secretary of the Sheffield Foreign Affairs Committee was a boy of eighteen, and Michael Beal subsequently described a visit to the Committee's rooms, where he found "Mr. Ironside by the fire and nobody with him". 4

By the beginning of the following year, as letters written to Robert Leader the Younger clearly show, Ironside was desperately eager to give up control of The Sheffield Free Press as well. ${ }^{5}$ The offer to sell at $£ 1,500$ ("but the transfer must take the thing clearly from me. I will have no responsibility of any kind") was not accepted, and the unfortunate Ironside was subsequently cheated out of $£ 250$ when William Cavill, a maker-up of the newspaper who had agreed to buy the business on the instalment plan for $£ 1,400$, absconded. ${ }^{6}$ The Sheffield Free Press came to an end on 26 December, 1857, and a legal squabble over unpaid wages was to provide a sordid epilogue to the whole affair.

Although the activities of the Sheffield Urquhartites in some ways draw attention to the fanatical and hysterical aspects of the national movement, in other ways they illustrate the links between Urquhartism and other aspects of contemporary thought at a variety of levels. In its widest aspects, Urquhartism, with its committees (like Owenism with its communities, Toulmin Smith's anarchism with it wardmotes and all those philosophies, including that underlying Disraeli's Sybil,

1857), p. 39; George Crawshay, The Immediate Cause of the Indian Mutiny (Newcastle-upon-Tyne, 1857), p. 31. Ironside's ridicule and abuse of Garibaldi also aroused great hostility. See The Sheffield Independent, 16 June, 1860, p. 10. 1 Ibid., 27 February, 1858, p. 10, and 8 May, 1858, p. 6.

2 Ibid., 28 March, 1857, p. 9. See also Isaac Ironside, The Part of France and Russia in the Surrender by England of the Right of Search (London, 1866).

3 The Sheffield Independent, 3 January, 1857, p. 6.

Ibid., 10 October, 1857 , p. 6; and 31 October, 1857 , p. 10.

5 See Ironside's letter to Robert Leader the Younger, The Leader Collection, Sheffield Central Library, Vol. 71, pp. 151-155.

- The Sheffield Independent, 30 May, 1857, p. 8, and 1 August, 1857, p. 8. 
which idealized a lost "Merrie England") was a revolt against the "universalized individuality" of a complex industrializing society in which, it was felt, the customary bonds between men and the restraints on their actions were being shattered forever. ${ }^{1}$ Here, in fact, was a consciousness of social malaise which Durkheim was to call anomie. Not surprisingly, Urquhartism, in Sheffield as elsewhere, found virtually no support from confident middle-class elements whose aggressive individualism found philosophical justification in the popularized doctrines of Adam Smith, Malthus and Ricardo.

In its finer aspects the Urquhartite movement also reflected that hatred of faction that characterized both the thought of Robert Owen, that most apolitical of all social philosophers with his "Association of all Classes of All Nations", and Benjamin Disraeli with his dream of a revitalized and responsible aristocracy rising above the machinations of sect and party. To Isaac Ironside, who constantly quoted Tom Paine's testament of faith "the world is my country, and to do good is my religion", Urquhartism was "not of the flesh". ${ }^{2}$ It was "neither municipal, national nor international, but something out of which everything right and good sprang ... accurate knowledge, unflinching integrity". The eradication of Russian influence in Britain would, he claimed, both purify and unify society; introduce the Englishman to the "orbed prospect of the renovation of his native land"; regenerate England, "and through England, the world". ${ }^{3}$ In this vision there are echoes of Godwin and a continuation of that millennial trend in ultra-Radical thought that E. P. Thompson has commented on in his Rise of the English Working Class (London, 1963).

At another level Urquhartism in Sheffield, like Isaac Ironside's earlier exposure of "abuses" in both local and national administration, might be looked upon as a somewhat bizarre expression of that spirit of fearless enquiry, rooted in the thought of Bentham and underlying those investigations, such as that which produced a monumental sanitary report in 1842, which laid the basis of a major revolution in public policy in Britain. Here again the Sheffield evidence provides

1 The degeneracy of contemporary society was a constant lament of The Free Press, and, as late as 1868 Ironside, who, two years before his death, was still proudly announcing himself as "the Chairman of the Sheffield Foreign Affairs Committee", was telling an audience that they "must do something, for society was falling to pieces as fast as it could." See The Sheffield Independent, 14 May, 1868, p. 3.

2 The Free Press, 3 May, 1856, p. 1.

3 Ibid., 9 February, 1856, p. 3. See also David Urquhart, An Appeal Against Faction (London, 1843). Apparently, in the Autumn of 1854, Ironside and his associates had tried to found a "Natural Party". See Ironside's letter to Gladstone, quoted by W. H. G. Armytage, op. cit., pp. 478-479. 
interesting links, for Ironside, a lifelong admirer of Bentham, whose works he said "served him as a rudder in the trackless ocean of politics", had contributed information to Edwin Chadwick, Bentham's leading disciple and the most determined of administrators. ${ }^{1}$

Ultimately, of course, the Urquhartite Movement reflected both the vitality and the complexity of the society that produced it. Superficially the product of an almost unbalanced mind, it came to reflect major trends in contemporary British thought and action. Nor are all the questions that were raised entirely solved or forgotten. There are still thinkers who would advocate the abolition of British embassies abroad - and it is perhaps paradoxical that a modern writer who has written scathingly about Urquhart holds just this view. And the still more important question remains: How can the individual play an interested, meaningful political rôle in an advanced society in which major decisions are increasingly in the hands of the faceless expert?

1 The Sheffield Iris, 19 November, 1842, p. 8; and 3 December, 1842, p. 3. 